\title{
A Review of Important QTLs for Biofortification Traits in Rice
}

\author{
Vinay Sharma ${ }^{1,2}$, Dinesh Kumar Saini ${ }^{3}$, Ashish Kumar ${ }^{4}$ and Prashant Kaushik, \\ 1 Department of Agricultural Biotechnology, Assam Agricultural University, Jorhat-785013 \\ 2 Division of Genetics, ICAR-Indian Agricultural Research Institute, New Delhi-110012 \\ 3 Department of Plant Breeding and Genetics, Punjab Agricultural University, Ludhiana 141004, India \\ 4 International Crops Research Institute for the Semi-Arid Tropics (ICRISAT), Hyderabad 502324, India \\ 5 Instituto de Conservación y Mejora de la Agrodiversidad Valenciana, Universitat Politècnica de \\ València, 46022 Valencia, Spain
}

* $\quad$ Correspondence. prakau@ doctor.upv.es

\begin{abstract}
Rice (Oryza sativa L.) supplies nourishment to about half of the population of the world's inhabitants. Of them, more than 2 billion people suffer from "hidden hunger" in which they are unable to meet the recommended nutrients or micronutrients from their daily dietary intake. Bio-fortification refers to developing micronutrient-rich diet foods using traditional breeding methods and modern biotechnology, a promising approach to nutrition enrichment as part of an integrated strategy for food systems. To improve the profile of rice grain for the biofortification related traits, understanding the genetics of important biofortification traits is required. Moreover, these attributes are quantitative in nature and are influenced by several genes and environmental variables. In the course of past decades, several endeavours such, as finding the important quantitative trait loci (QTLs) for improving the nutrient profile of rice seeds were successfully undertaken. In this review, we have presented the information regarding the QTLs identified for the biofortification traits in the rice.
\end{abstract}

Keywords: QTLs; biofortification; malnutrition; hidden hunger; marker-assisted breeding

\section{Introduction}

RICE (Oryza sativa L.) provides energy and nutrition to almost half of the world's population ${ }^{1}$. In most developing countries, especially in Asia, rice is consumed in significant quantities and is the main component diet. In the present scenario, high yielding rice varieties are low in mineral elements. Milled or polished rice is not a significant source of any major mineral elements and therefore, it can't meet up with the recommended daily dietary intake for mineral elements. Moreover, around 792.5 million people across the world are malnourished, out of which 780 million people live in developing countries ${ }^{2}$. Thus, most riceeating, resource-poor people in Southeast Asia, Africa and Latin America suffer from chronic micronutrient malnutrition, often referred to as hidden hunger ${ }^{3}$.

Protein-energy malnutrition affects $25 \%$ of children those with the dietary intake of predominantly rice, and staple crops have low levels of an essential amino acid ${ }^{4}$. Further, rice has relatively low $(8.5 \%)$ protein content as compared to other cereals such as wheat, barley and millets. Moreover, the average protein content in milled rice is around $7 \%$. However, the total seed protein content of rice consists of 60-80\% glutelin and 20-30\% prolamin ${ }^{5}$. Interestingly, rice supplies about $40 \%$ of the total protein requirement of humans in developing countries ${ }^{6}$. 
Phytate is a crucial mineral storage compound in seed, with a mixed cation salt of phytic acid accounting for approximately $75 \%$ of total seed phosphorus content ${ }^{7}$. The significant portion of the phosphorus taken from the soil by plants is ultimately translocated to the seed and further synthesized into phytic acid. Phytate is vital for the development of seeds and also as an antioxidant, anticancer agent, lowering chronic disease rates, and preventing coronary disease ${ }^{8}$. Phytic acid known as an anti-nutritional factor because it forms complexes in seeds with proteins and essential minerals such as $\mathrm{Fe}, \mathrm{Zn}$, and $\mathrm{Ca}^{9}$ and leads to impair the bioavailability of the same.

Mineral elements are critical for several cellular and metabolic activities ${ }^{10}$. Biofortification of staple crops provides a sustainable methodology to triumph over the mineral deficiency. Attempts were made for the development, release and distribution of Biofortified crops with the help of agronomic practices, biotechnological techniques and also by using plant breeding methods. Various old rice varieties with high grain iron and zinc content were screened, and breeding methods with improved agronomic characteristics combined the higher mineral characteristics. In 2013, the Bangladesh Rice Research Institute released zinc-enriched rice varieties (BRRIdhan 62, BRRIdhan 72, and BRRIdhan 64), claiming to contain 20-22 ppm of zinc in brown rice. An improved line (IR68144-3B-2-2-3) has been identified in India and Philippines in a cross between a high yielding variety (IR72) and a large, traditional variety (ZawaBonday) with a top grain iron concentration about $21 \mathrm{ppm}$ in brown rice ${ }^{11}$.

Similarly, Jalmagna, a traditional variety with almost double the iron and zinc concentration of common rice variety, has been identified for further breeding programs to improve iron and zinc concentration by nearly 40 percent more than that of conventional rice variety $^{11}$. ICAR-Indian Institute of Rice Research, Hyderabad, Telangana developed biofortified pure line variety, DRR Dhan 45. It possesses high zinc (22.6 ppm) in polished grain. It has been released and notified in 2016 for Karnataka, Tamil Nadu, Andhra Pradesh and Telangana. Its average grain yield is $50.0 \mathrm{q} / \mathrm{ha}$. It matures in 125-130 days ${ }^{12,13}$. Another pureline variety DRR Dhan 49 with high zinc $(25.2 \mathrm{ppm})$ in polished grain released and notified in 2018 for Gujarat, Maharashtra and Kerala. Its average grain yield is 50.0 q/ha and matures in 125-130 days ${ }^{13}$.

Mineral element accumulation in the grain is a complex process and is highly influenced by environmental factors. This resulted in less effective early-generation phenotypic selections for mineral grain elements and slowed progress in the breeding of biofortified rice varieties ${ }^{14}$. In-depth understanding of the genetic basis of mineral elements at the molecular level and the identification of significant effects of QTLs can help to speed up the development of biofortified rice varieties through marker-assisted breeding ${ }^{15}$. Rice is a model for cereal crops. Vast genomic resources are available, including genome-wide single nucleotide polymorphic (SNP) molecular markers and various advanced genomic platforms, to enable complex traits to be dissected at the molecular level ${ }^{16}$. Several studies to chart QTLs for biofortified traits include the use of introgression lines (ILs) ${ }^{17}$ and double haploids (DHs) to uncover QTLs ${ }^{18}$. However, the stability of released genotypes is an important consideration to hope for a meticulous performance of released genotypes for stable produce for the farmers ${ }^{19,20}$. Hence, molecular breeding approach for biofortification of crop offers a sustainable and long-term solution. Also, biofortified crops with increased bioavailability of 
essential protein, vitamins and micronutrients are deployed to consumers through traditional farming and food trading practices, thus providing a feasible way to reach undernourished and low-income families with limited access to various diets, supplements and fortified foods $^{21}$.

\section{Protein content in rice}

Grain protein content (GPC) in rice is one of the major factors which decides the nutritional value of rice food and influences the palatability of cooked rice ${ }^{22}$. Rice's seed protein content consists of 60-80\% glutelin and 20-30\% prolamin, regulated by 15 and 34 genes respectively ${ }^{5}$. It supplies about $40 \%$ of the protein to humans through diet in developing nations, and rice GPC quality is high owing to lysine richness $(3.8 \%)^{6}$. Improving GPC in rice grain is, therefore, a significant goal for plant breeders and biotechnologists. More than twenty QTL mapping studies have been conducted in the last two decades to explore the genetic base of the protein content in rice. Moreover, to our knowledge, more than eighty stable and consistent QTLs for GPC have been identified and mapped on all twelve chromosomes of rice, although the majority of them were mapped on chromosomes 1 , 2, 6, 7, 10 and 11 (Table 1). For the first time, Tan et al. ${ }^{23}$ mapped two QTLs, one in the interval of markers C952-Wx on chromosome 6 , with the phenotypic variance explain (PVE) $13.0 \%$; and the other one in the interval markers R1245-RM234 on chromosome 7 with PVE 6.0\%. In another study, Aluko et al. ${ }^{24}$ identified and mapped four QTLs among $312 \mathrm{DH}$ lines derived from the $\mathrm{BC}_{3} \mathrm{~F}_{1}$ of an interspecific cross of $O$. sativa $\times$ O. glaberrima explaining the phenotypic variance of 4.8 to $15.0 \%$. Among the four QTLs, one QTL, pro6 was closely associated with $W x$ gene influencing rice quality. Thereafter, a number of studies have been conducted to map the QTLs regulating GPC in rice ${ }^{25-29}$.

Zheng et al..$^{30}$ employed unconditional and conditional QTL mapping methods to analyse the developmental behaviour of protein content and protein index in rice. At four stages of grain filling viz. 7, 14, 21 and 28 DAF, they mapped 10 unconditional QTLs and 6 conditional QTLs, explaining 8.53-19.59\% and 8.76-23.70\% of PVE for GPC, respectively, and 11 unconditional QTLs and 9 conditional QTLs explaining 7.46-16.97\% and 7.46-18.88 $\%$ of PVE for protein index, respectively. A strategy to detect more QTLs for rice grain quality within sub-populations ${ }^{31}$. Xu et al. ${ }^{32}$ detected a total of 29 QTLs in the whole population, and ten QTLs in the two sub-populations for seven traits, four of which (one qPRO3.1 for protein content) were detected in the entire population but remaining six QTLs were not. These six QTLs with minor effects might have covered by the $W x$ locus when mapped in the whole population. In addition to usual biparental populations such as recombinant inbred lines, backcross inbred lines and doubled haploid lines, advanced population, i.e. chromosome segment substitution line (CSSL) populations have also been employed $^{33}$. Yang et al. ${ }^{33}$ used a CSSL population derived from the cross of a Japonica variety (Sasanishiki) with Indica variety (Habataki) and identified a total of seven QTLs in three environments, although only one QTL $(q P C-1)$ was detected across three environments explaining 10.38-15.43\% of PVE.

Furthermore, they developed $\mathrm{F}_{2}$ and $\mathrm{F}_{3}$ segregating populations from the cross between a CSSL with low PC, SL402, harbouring $q P C-1$ and Sasanishiki, and delimited the region of $q P C-1$ to a $41-\mathrm{kb}$ on chromosome 1 . These results may be helpful to introgress the 
QTL for GPC into rice cultivars using marker assisted selection. In one study, Bruno et al. ${ }^{34}$ observed compromised heritability percentage for protein whereas higher heritability percentage for the amylose content in a DH population derived from a cross between Cheongcheong and Nagdong. They mapped a QTL for GPC on chromosome 7 linked with the marker RM8261, explaining $14 \%$ of PVE.

As has been shown by previous studies, identification of robust QTLs for GPC in rice grains have been restricted because of lack of appropriate donors, non-utilization of high throughput phenotyping and genotyping platforms and high genotype $\times$ environment $(\mathrm{G} \times \mathrm{E})$ interaction. To overcome these restrictions, recently Chattopadhyay et al. ${ }^{35}$ genotyped a $\mathrm{BC}_{3} \mathrm{~F}_{4}$ mapping population derived from the cross between grain protein donor, ARC10075 and high-yielding cultivar Naveen, using $40 \mathrm{~K}$ Affymetrix custom SNP array and identified three stable QTLs (namely, qGPC1.1, qSGPC2.1 and $q S G P C 7.1$ ) for GPC explaining 13\%, $14 \%$ and $7.8 \%$ of PVE, respectively. QTLs identified in these study can be useful to improve the nutritional quality of rice grain. The closely linked markers that flanked the identified QTLs can be used to aid quality selection in breeding programs. And the results of the coincidence between the QTL detected, and the loci involved in protein biosynthesis pathways might be helpful for gene cloning by the candidate gene method.

\section{Amino acid content}

In addition to GPC, improvement in the amino acid composition is important to meet the food demands of a growing global population. A major function of proteins in nutrition is to supply adequate amounts of required amino acids ${ }^{36,37}$. Depending on requirement and availability in animal metabolic processes, Essential amino acids cannot be synthesized by animals, but play a crucial role in metabolism ${ }^{38}$. Therefore, improving amino acid content in rice grain is an important objective. Several studies using the linkage mapping approach with various mapping populations have provided useful genetic information for improving the amino acid composition (AAC) in rice grains. Wang et al. ${ }^{39}$ identified 18 chromosomal regions for 19 components of AAC in two years viz. 2002 and 2004. They found total ten QTL clusters in 2002 and six in 2004.

Interestingly, they also detected wide coincidence between the QTLs and the loci involved in amino acid metabolism pathways, including $\mathrm{N}$ assimilation, transfer and protein biosynthesis. In a similar study, Zhong et al. ${ }^{25}$ reported 48 and 64 QTLs each contributing $4.0 \%$ to $43.7 \%$ to the total phenotypic variance, in 2004 and 2005 , respectively. They also reported good coincidence between the detected QTL and the loci involved in amino acid metabolism pathways in nitrogen assimilation and transport, or protein biosynthesis. In another study, Zheng et al..$^{40}$ mapped a total of ten QTLs explaining 12-35\% of PVE for histidine on chromosomes 1, 2, 3, 6, 7, 10, 11, and 12; and 8 QTLs explaining 16-33\% of PVE for arginine on chromosomes 2, 3, 5, 6, 7, 10, 11, and 12. All QTLs showed significant additive effects from the triploid endosperm and diploid maternal plant while 2 QTLs for Histidine and 2 for Arginine content also showed significant dominant main effects from the triploid endosperm. Various interactions between QTLs and environment were detected for 5 QTLs associated with Histidine content and 2 QTLs associated with Arginine contents. QTLs associated with amino acid contents and linked/flanking markers are summarized in Table 1. Recently, Yoo $^{41}$ mapped a total of six main-effect QTLs located on chromosome 3, 
contributing 10.2-12.4\% PVE for the content of six amino acids. The QTL cluster (qAla3, qVal3, qPhe3, qIle3, and qLeu3) in the interval of markers id3015453 and id3016090, was found to be associated with the contents of five amino acids and accounted for PVE from 10.2 to $12.8 \%$. Although, they also detected 26 digenic interactions for the content of seven amino acids viz. Asp, Ser, His, Gly, Arg, Ala, and Tyr involving 25 loci distributed on the nine chromosomes but they did not find any interaction for the other nine amino acids. Therefore, these identified QTLs results will be useful to find the candidate genes and favourable alleles for the enrichment of nutritional value in rice grain.

\section{$\mathrm{Zn}$ and Fe contents in rice}

Zn deficiency in grown-up children and adolescent males causes retarded growth and dwarfism, retarded sexual development, impaired sense of taste and poor appetite and mental lethargy ${ }^{42}$. Several roles of zinc found involved in an abundant no. of proteins in biological systems to maintain their structural stability function. It has found that $\mathrm{Zn}$ is essential for gene regulation and expression under stress conditions and is therefore required for protection against infections and disease ${ }^{43}$. Likewise, iron has so many vital functions in the body like as a carrier of oxygen to the tissues from the lungs ${ }^{44}$.

In last two decades, more than 80 QTLs have been identified and mapped on all twelve chromosomes of rice for zinc and iron contents using various mapping populations derived from different intraspecific and interspecific crosses. QTLs associated with zinc and iron contents and linked/flanking markers are summarized in Table 1. As per our knowledge, for the first time, Stangoulis et al. ${ }^{18}$ mapped two QTLs for Zn and three QTLs for Fe on chromosomes 1, 2, 8 and 12 explaining 12.8 to $15 \%$ and 13.8 to $18.3 \%$ of PVE, respectively. Besides, Garcia- Oliveira et al. ${ }^{17}$ detected one major effect QTL explaining most significant proportion of PVE (11\%-19\%) for zinc, flanking by SSR marker RM152 on chromosome 8. In other various studies, several QTLs have been reported which explained a large amount of PVE either for zinc or for both iron and zinc contents ${ }^{45-51}$.

Ishikawa et al. ${ }^{52}$ mapped four QTLs on chromosomes 2, 9, and 10 explaining 15.0$21.9 \%$ of PVE for grain zinc content using backcross recombinant inbred lines (BRILs) derived from $O$. sativa 'Nipponbare' and $O$. meridionalis W1627. Further, they fine mapped QTL (named $q G Z n 9$ ) present on chromosome 9, and identified two tightly linked loci, $q G Z n 9 a$ (candidate region-190 kb) and $q G Z n 9 b(950 \mathrm{~kb})$. They also showed the association of wild chromosomal segment covering $q G Z n 9 a$ with fertility reduction and hence they recommended the use of $q G Z n 9 b$ as a valuable allele for breeding rice with high $\mathrm{Zn}$ in the grains. In another study, Swamy et al. ${ }^{53}$ identified 20 QTLs for agronomic traits and total 59 QTLs for several biofortification traits including eight QTLs for grain zinc and one QTL for grain iron, mapped on chromosomes $2,3,4,6,8,11$ and 12. They also detected eight epistatic interactions for $\mathrm{Zn}, \mathrm{Cu}, \mathrm{Mg}$ and $\mathrm{Na}$ in a double haploid population.

Furthermore, they identified several candidate genes near grain zinc QTL (OSNRAMP, OsNAS, OsZIP, OSYSL, OSFER, and OsZIFL family), which may be useful for marker-assisted breeding for this important trait. Recently in 2019, two critical studies were conducted, in first study, Descalsota-Empleo et al. ${ }^{44}$ phenotyped two DH populations at two seasons and genotyped with a 6 K SNP chip, and identified total 15 QTL for agronomic traits 
and 50 QTL for grain element concentration including eight QTLs explaining 8.6 to 27.7\% PVE for grain zinc. They also analyzed the combined effect of QTL in both populations. Among the single-QTL lines, those with $q Z n 9.1$ showed highest mean grain $\mathrm{Zn}$ of 18.1 and $19.1 \mathrm{mg} \mathrm{kg}^{-1}$ in two consecutive seasons, respectively. They reported an increase in the content of zinc with the increase in number of QTLs and observed highest grain Zn of 28.2 and $24.3 \mathrm{mg} \mathrm{kg}^{-1}$ in two seasons, respectively in four QTL line $(q Z n 2.1+q Z n 5.1+q Z n 5.1+q Z n 11.1)$. Their results showed the possibility of QTLpyramiding for improving the zinc content in rice. In another study, Kumar et al. ${ }^{55}$ detected one QTL for Zn and five QTL for Fe having PVE 25\% and 34.6 to 95.2\% respectively, using $\mathrm{F}_{4}$ Population (579 individuals) derived from a cross between PAU201 and Palman. These identified QTLs can significantly enhance the efficacy of breeding programs to improve the $\mathrm{Zn}$ and Fe density in rice.

\section{Phytic acid}

Phytic acid is an essential constituent in staple foods like legume and cereals, which has been of much concern ${ }^{56}$. In addition of its beneficial effect on human health, it has some anticancer and anti-oxidant functions and prevents coronary disease, it is well known that phytic acid acts as strong chelating agent of mineral nutrients such as $\mathrm{Ca}, \mathrm{Zn}$ and $\mathrm{Fe}^{56}$. It has seen that the presence of complex of phytic acid, in the form of phytate, there is a significant reduction found in bio-availability of nutrient elements ${ }^{57}$. It seems reasonable to control phytic acid contents in edible parts of crops to a level in which the medical and health functions of the food may be maintained, and bio-availability of minerals is not much altered $^{58}$.

Liu et al..$^{59}$ assayed 72 cultivars for protein content and phytic acid and reported a wide range for phytic acid ranged from $0.685 \%$ to $1.03 \%$, with a an average of $0.873 \%$. Interestingly, grain phytic acid and protein content were not correlated, which suggests the possibility of breeding rice for phytic acid and high protein content. Furthermore, they also reported a significant effect of varieties, locations and their interactions on phytic acid content, with the location having the most considerable impact which suggests the necessity of multi-environment trials for the accurate evaluation of rice germplasm for phytic acid content.

Although, sufficient genetic variation for phytic acid has been reported in various studies $^{59,60}$, unfortunately, only one study has been conducted to map the QTLs for phytic acid in rice ${ }^{18}$. Stangoulis et al. ${ }^{18}$ identified two QTLs explaining 15.4-24.3\% of PVE for grain phytates from an IR64 $\times$ Azucena double haploid population. One common QTL for phytate and total $\mathrm{P}$ concentrations on chromosome 5 with the (high concentration) allele contributed from Azucena was identified. Furthermore, it was reported that Fe, $\mathrm{Zn}$ and $\mathrm{Mn}$ contents in grains have different genetic regulation because the QTLs of phytate was not located on the same chromosomal regions as those found for $\mathrm{Fe}, \mathrm{Zn}$ and $\mathrm{Mn}^{18}$. So, there is a great possibility to find segregants having a low level of phytic acid and high level of Fe, $\mathrm{Zn}$ and $\mathrm{Mn}$ content. The use of molecular markers in breeding and selection to reduce the grain phytic acid and improving the nutritional value of cereal grains.

\section{Conclusions and Future Prospects}


Biofortification is a promising, cost-effective, agricultural strategy to improve the nutritional status of the worlds under nourished populations. Strategies for Biofortification based on crop breeding, targeted genetic manipulation and/or mineral fertilizer application have great potential to address human mineral malnutrition. Developing biofortified food crops with improved nutrient content such as increased content of iron, zinc, Se, and provitamin A provides adequate levels of these and other such micronutrients that are often lacking in developed and developing diets. International initiatives, such as the CGIAR centres in collaboration with HarvestPlus and national initiatives, serve as pillars for achieving these objectives.

These efforts have resulted in crops with the potential to increase both quantities and bioavailability of essential mineral elements in human diets, particularly in elementary cereal crops such as rice, wheat, maize, cassava, beans and sweet potatoes. However, crop biofortification is a challenging task. Collaboration between plant breeders, nutritionists, genetic engineers, and molecular biologists is essential to achieving this. Breeding approaches are generalized and easy to accept and have been used to improve food nutritional qualities sustainably. While the greater emphasis is placed on molecular breeding based approaches of which success rates are much higher as transgenically fortified crop plants. It faces hurdles due to consumer acceptance, costly and time-consuming regulatory approval processes adopted by different countries. Biofortified crops have a very bright future in addition to these challenges, as they have the potential to eliminate micronutrient malnutrition among billions of poor people, particularly in developing countries.

Conflict of interest: The authors declare that they have no conflict of interest.

\section{References}

1. GRiSP (Global Rice Science Partnership). Rice almanac, 4th edition. Los Baños (Philippines), International Rice Research Institute., 2013.

2. McGuire, S. FAO, IFAD, and WFP. The state of food insecurity in the world 2015: meeting the 2015 international hunger targets: taking stock of uneven progress. Rome: FAO. Adv Nutr., 2015, 6, 623.

3. Muthayya, A., Rah, J. H., Sugimoto, J. D., Roos, F. F., Kraemer, K. and Black, R. E. The global hidden hunger indices and maps: an advocacy tool for action. PLoS One. 2013, 8(6), e67860.

4. Gearing, M. E., Good as gold: Can golden rice and other biofortified crops prevent malnutrition. Science in the News, Harvard University, 2015, http://sitn.hms.harvard.edu.

5. $\mathrm{Xu}, \mathrm{J} . \mathrm{H}$, and Messing, J., Amplification of prolamin storage protein genes in different subfamilies of the Poaceae. Theor Appl Genet. 2009, 119, 1397.

6. Shobha, Rani., N, Pandey., M. K., Prasad, G. S. V. and Sudharshan, I., Historical significance, grain quality features and precision breeding for improvement of export quality basmati varieties in India. J Crop Sci. 2006, 1, 29.

7. Raboy, V., Approaches and challenges to engineering seed phytate and total phosphorus. Plant Sci. 2009, 177, 281. 
8. Gemede, H. M., Potential health benefits and adverse effects associated with phytate in foods. Food Sci Qual Manag. 2014, 27, 45.

9. Tamanna, S., Sayma, P., Sanjay, K., Alak, K. D., Aysha, F. M., Ali, S., Sunil, K. B., Zakir, M. and Howlader, H., Content of some minerals and their bioavailability in selected popular rice varieties from Bangladesh. Int J Curr Microbiol Appl Sci. 2013, 2,35 .

10. Institute of Medicine Food and Nutrition Board (IMFNB). Dietary reference intakes for Vitamin A, Vitamin K, Arsenic, Boron, Chromium, Copper, Iodine, Iron, Manganese, Molybdenum, Nickel, Silicon, Vanadium and Zinc. National Academy Press, Washington, 2001.

11. Gregorio, G. B., Senadhira, D., Htut, H. and Graham, R. D., Breeding for trace mineral density in rice. Food Nutr Bull. 2000, 21, 382.

12. Yadava, D. K., Choudhury, P. R., Hossain, F., Kumar, D. Biofortified varieties: Sustainable way to alleviate malnutrition. New Delhi: Indian Council of Agricultural Research, 2017.

13. Yadava, D. K., Hossain, F., Choudhury, P. R., Kumar, D., Singh, A. K. Biofortification of crops: A sustainable tool for nutritional security in India. Indian Farming. 2018, 68, 37-42.

14. Perez-de-Castro, A. M., Vilanova, S., Canizares, J., Pascual, L., Blanca, J. M., Diez, M. J., Prohens J. and Pico, B., Application of genomic tools in plant breeding. Curr Genomics. 2012, 13, 179.

15. Zhang, M., Pinson, S. R., Tarpley, L., Huang, X. Y., Lahner, B., Yakubova, E., Baxter, I., Guerinot, M. L. and Salt, D. E., Mapping and validation of quantitative trait loci associated with concentrations of 16 elements in unmilled rice grain. Theor Appl Genet. 2014, 127, 137.

16. McCouch, S. R., Wright, M. H., Tung, C. W., Maron, L. G., McNally, K. L., Fitzgerald, M., Singh, N., DeClerck, G., Agosto-Perez, F., Korniliev, P. and Greenberg, A. J., Open access resources for genome-wide association mapping in rice. Nat Commun. 2016, 7, 10532.

17. Garcia-Oliveira, A. L., Tan, L., Fu, Y. and Sun, C., Genetic identification of quantitative trait loci for contents of mineral nutrients in rice grain. $J$ Integr Plant Biol. 2009, 51, 84.

18. Stangoulis, J. C., Huynh, B. L., Welch, R. M., Choi, E. Y. and Graham, R. D., Quantitative trait loci for phytate in rice grain and their relationship with grain micronutrient content. Euphytica. 2007, 154, 289.

19. Jain, B. T., Sarial, A. K. and Prashant, K., Stability analysis utilizing AMMI model and regression analysis for grain yield of Basmati rice (Oryza sativa L.) genotypes. JEBAS. 2018, 6, 522.

20. Jain, B., Sarial, A. and Kaushik, P., Understanding G x E Interaction of Elite Basmati Rice (Oryza sativa L.) Genotypes under North Indian Conditions Using Stability Models. ApplEcolEnv Res. 2019, 17, 5863.

21. Hefferon, K. L., Can biofortified crops help attain food security. CurrMolBiol Rep. 2016, 2, 180. 
22. Matsue, Y., Odahara, K. and Hiramatsu, M., Differences in amylose content, amylographic characteristics and storage proteins of grains on primary and secondary rachis branches in rice. Jpn J Crop Sci. 1995, 64, 601.

23. Tan, Y. F., Sun, M., Xing, Y. Z., Hua, J. P., Sun, X. L., Zhang, Q. F. and Corke, H., Mapping quantitative trait loci for milling quality, protein content and color characteristics of rice using a recombinant inbred line population derived from an elite rice hybrid. TheorAppl Genet. 2001, 103, 1037.

24. Aluko, G., Martinez, C., Tohme, J., Castano, C., Bergman, C. and Oard, J. H., QTL mapping of grain quality traits from the interspecific cross Oryza sativax O. glaberrima.TheorAppl Genet. 2004, 109, 630.

25. Zhong, M., Wang, L. Q., Yuan, D. J., Luo, L. J., Xu, C. G. and He, Y. Q., Identification of QTL affecting protein and amino acid contents in rice. Rice Science. 2011, 18, 187.

26. Zheng, L., Zhang, W., Liu, S., Chen, L., Liu, X., Chen, X., Ma, J., Chen, W., Zhao, Z., Jiang, L. and Wan, J., Genetic relationship between grain chalkiness, protein content, and paste viscosity properties in a backcross inbred population of rice. $J$ Cereal Sci. 2012, 56, 153.

27. Lee, G, H., Yun, B. W. and Kim, K. M., Analysis of QTLs associated with the rice quality related gene by double haploid populations. Int J Genomics. 2014.

28. Leng, Y., Xue, D., Yang, Y., Hu, S., Su, Y., Huang, L., Wang, L., Zheng, T., Zhang, G., Hu, J. and Gao, Z., Mapping of QTLs for eating and cooking quality-related traits in rice (Oryza sativa L.). Euphytica. 2014, 197, 99.

29. Yun, B. W., Kim, M. G., Handoyo, T. and Kim, K. M., Analysis of rice grain qualityassociated quantitative trait loci by using genetic mapping. AJPS. 2014, 5(09) 1125.

30. Zheng, L., Zhang, W., Chen, X., Ma, J., Chen, W., Zhao, Z., Zhai, H. and Wan, J., Dynamic QTL analysis of rice protein content and protein index using recombinant inbred lines. J Plant Biol. 2011, 54,321.

31. Xu, F., Sun, C., Huang, Y., Chen, Y., Tong, C. and Bao, J., QTL mapping for rice grain quality: a strategy to detect more QTLs within sub-populations. Mol Breed. 2015, 35, 105.

32. Xu, Q., Zheng, T. Q., Hu, X., Cheng, L. R., Xu, J. L., Shi, Y. M. and Li, Z. K., Examining two sets of introgression lines in rice (Oryza sativa L.) reveals favorable alleles that improve grain $\mathrm{Zn}$ and Fe concentrations. PloS one., 2015, 10, p.e 0131846.

33. Yang, Y., Guo, M., Li, R., Shen, L., Wang, W., Liu, M., Zhu, Q., Hu, Z., He, Q., Xue, Y. and Tang, S., Identification of quantitative trait loci responsible for rice grain protein content using chromosome segment substitution lines and fine mapping of qPC-1 in rice (Oryza sativa L.). Mol Breed. 2015, 35, 130.

34. Bruno, E., Choi, Y. S., Chung, I. K. and Kim, K. M., QTLs and analysis of the candidate gene for amylose, protein, and moisture content in rice (Oryza sativa L.). 3 Biotech. 2017, 7, 40.

35. Chattopadhyay, K., Behera, L., Bagchi, T. B., Sardar, S. S., Moharana, N., Patra, N. R., Chakraborti, M., Das, A., Marndi, B. C., Sarkar, A. and Ngangkham, U., Detection of stable QTLs for grain protein content in rice (Oryza sativa L.) employing high throughput phenotyping and genotyping platforms. Sci. Rep. 2019, 9, 3196. 
36. Friedman, M., Brandon, D. L., Nutritional and health benefits of soy proteins. $J$. Agric. Food Chem. 2001, 49, 1069-1086.

37. Panthee, D. R., Pantalone, V. R., Saxton, A. M., West, D. R. and Sams, C. E., Genomic regions associated with amino acid composition in soybean. Mol. Breed. 2006, 17, 79-89.

38. D’Mello, J. P. F., Amino acids as multifunctional molecules. In: D’Mello JPF, ed. Amino Acids in Animal Nutrition (2nd ed.). CABI Publishing, Cambridge, MA, 2003, pp.1-14.

39. Wang, L., Zhong, M., Li, X., Yuan, D., Xu, Y., Liu, H., He, Y., Luo, L. and Zhang, Q., The QTL controlling amino acid content in grains of rice (Oryza sativa) are colocalized with the regions involved in the amino acid metabolism pathway. Mol Breed. 2008, 21, 127.

40. Zheng, X., Jian-Guo, W. U., Xiang-Yang, LOU., Hai-Ming, XU., and Chun-Hai, SHI., QTL Analysis of maternal and endosperm genomes for histidine and arginine in rice (Oryza sativa L.) across environments. Acta Agronomica Sinica. 2008, 34, 369.

41. Yoo S. C., Quantitative trait loci controlling the amino acid content in rice (Oryza sativa L.). J Plant Biotechnol. 2017, 44, 349.

42. Hambidge, M., Human zinc deficiency. J Nutr., 2000, 130(5), 1344S-1349S.

43. FAO/WHO. Vitamin and mineral requirements in human nutrition. World Health Organization. Geneva, 2nd edn, 2005.

44. Kühn, L. C., Control of cellular iron transport and storage at the molecular level. In: Hallberg L, Asp N-G, eds. Iron nutrition in health and disease. London, John Libbey, 1996, 17-29.

45. Lu, K., Li, L., Zheng, X., Zhang, Z., Mou, T. and Hu, Z., Quantitative trait loci controlling $\mathrm{Cu}, \mathrm{Ca}, \mathrm{Zn}, \mathrm{Mn}$ and Fe content in rice grains. J Genet. 2008, 87, 305.

46. Norton, G. J., Deacon, C. M., Xiong, L., Huang, S., Meharg, A. A. and Price, A. H., Genetic mapping of the rice ionome in leaves and grain: identification of QTLs for 17 elements including arsenic, cadmium, iron and selenium. Plant Soil. 2010, 329, 139.

47. Zhang, X., Zhang, G., Guo, L., Wang, H., Zeng, D., Dong, G., Qian, Q. and Xue, D., Identification of quantitative trait loci for $\mathrm{Cd}$ and $\mathrm{Zn}$ concentrations of brown rice grown in Cd-polluted soils. Euphytica. 2011, 180, 173.

48. Anuradha, K., Agarwal, S., Rao, Y. V., Rao, K. V., Viraktamath, B. C. and Sarla, N., Mapping QTLs and candidate genes for iron and zinc concentrations in unpolished rice of Madhukar× Swarna RILs. Gene. 2012, 508, 233.

49. Kumar, J., Jain, S. and Jain R. K., Linkage mapping for grain iron and zinc content in F2 population derived from the cross between PAU201 and Palman 579 in rice (Oryza sativa L.). Cereal Res Commun. 2014, 42, 389.

50. Indurkar, A. B., Majgahe, S. K., Sahu, V. K., Vishwakarma, A., Premi, V. and Shrivastatva, P., Identification, Characterization and Mapping of QTLs related to Grain Fe, Zn and Protein Contents in Rice (Oryza sativa L.). Electron J Plant Breed. 2015, 6, 1059.

51. Hu, B. L., Huang, D. R., Xiao, Y. Q., Fan, Y. Y., Chen, D. Z. and Zhuang, J. Y., Mapping QTLs for mineral element contents in brown and milled rice using an Oryza 
sativa $\times$ O. rufipogon backcross inbred line population. Cereal Res Commun. 2016, 44, 57.

52. Ishikawa, R., Iwata, M., Taniko, K., Monden, G., Miyazaki, N., Orn, C., Tsujimura, Y., Yoshida, S., Ma, J. F. and Ishii, T., Detection of quantitative trait loci controlling grain zinc concentration using Australian wild rice, Oryza meridionalis, a potential genetic resource for biofortification of rice. PloS one. 2017, 12, pe0187224.

53. Swamy, B. M., Descalsota, G. I. L., Nha, C. T., Amparado, A., Inabangan-Asilo, M. A., Manito, C., Tesoro, F. and Reinke, R., Identification of genomic regions associated with agronomic and biofortification traits in $\mathrm{DH}$ populations of rice. PloS one. 2018, 13, p.e0201756.

54. Descalsota-Empleo, G. I., Amparado, A., Inabangan-Asilo, M. A., Tesoro, F., Stangoulis, J., Reinke, R. and Swamy, B. M., Genetic mapping of QTL for agronomic traits and grain mineral elements in rice. The Crop J. 2019.

55. Kumar, N., Jain, R. K. and Chowdhury, V. K., Linkage mapping of QTLs for grain minerals (iron and zinc) and physio-morphological traits for development of mineral rich rice (Oryza sativa L.). 2019.

56. Harland, B. F., and Morris, E. R., Phytate: A good or a bad food component? Nutrition Research., 1995, 15, 733-754.

57. Erdman, J. W., Bioavailability of trace minerals from cereals and legumens. Cereal Chemistry. 1981, 58, 21-26.

58. Febles, C. I., Arias, A., Hardisson, A., Rodriguez-Alvarez, C., and Sierra, A. Phytic acid level in wheat flours. Journal of Cereal Science. 2002, 36, 19-23.

59. Liu, Z., Cheng, F. and Zhang, G., Grain phytic acid content in japonica rice as affected by cultivar and environment and its relation to protein content. Food Chem. 2005, 89, 49.

60. Liu, Q, L., Xu, X. H., Ren, X. L., Fu, H. W., Wu, D. X. and Shu, Q. Y., Generation and characterization of low phytic acid germplasm in rice (Oryza sativa L.). TheorAppl Genet. 2007, 114, 803.

61. Lu, K., Li, L., Zheng, X., Zhang, Z., Mou, T. and Hu, Z., Genetic dissection of amino acid content in rice grain. J Sci Food Agric. 2009, 89, 2377.

62. Hu, Z. L., Li, P., Zhou, M. Q., Zhang, Z. H., Wang, L. X., Zhu, L. H. and Zhu, Y. G., Mapping of quantitative trait loci (QTLs) for rice protein and fat content using doubled haploid lines. Euphytica. 2004, 135, 47.

63. Li, J., Xiao, J., Grandillo, S., Jiang, L., Wan, Y., Deng, Q., Yuan, L. and McCouch, S. R., QTL detection for rice grain quality traits using an interspecific backcross population derived from cultivated Asian (O. sativa L.) and African (O. glaberrima S.) rice. Genome. 2004, 47, 697.

64. Wada, T., Uchimura, Y., Ogata, T., Tsubone, M. and Matsue, Y., Mapping of QTLs for physicochemical properties in japonica rice. Breeding Sci. 2006, 56, 253.

65. Takeuchi, Y., Nonoue, Y., Ebitani, T., Suzuki, K., Aoki, N., Sato, H., Ideta, O., Hirabayashi, H., Hirayama, M., Ohta, H. and Nemoto, H., QTL detection for eating quality including glossiness, stickiness, taste and hardness of cooked rice. Breeding Sci. 2007, 57, 231. 
66. Zhang, X., Zhang, G., Guo, L., Wang, H., Zeng, D., Dong, G., Qian, Q. and Xue, D., Identification of quantitative trait loci for $\mathrm{Cd}$ and $\mathrm{Zn}$ concentrations of brown rice grown in Cd-polluted soils. Euphytica. 2011, 180, 173.

67. Lou, J., Chen, L., Yue, G., Lou, Q., Mei, H., Xiong, L. and Luo, L., QTL mapping of grain quality traits in rice. J Cereal Sci. 2009, 50, 145.

68. Yu, Y. H., Li, G., Fan, Y. Y., Zhang, K. Q., Min, J., Zhu, Z. W. and Zhuang, J. Y., Genetic relationship between grain yield and the contents of protein and fat in a recombinant inbred population of rice. J Cereal Sci. 2009, 50, 121.

69. Shi, C. H., Shi, Y., Lou, X. Y., Xu, H. M., Zheng, X. and Wu, J. G., Identification of endosperm and maternal plant QTLs for protein and lysine contents of rice across different environments. Crop Pasture Sci. 2009, 60, 295.

70. Qin, Y., Kim, S. M. and Sohn, J. K., QTL analysis of protein content in doublehaploid lines of rice. Korean J Crop Sci. 2009, 54, 165. 
Table 1. List of QTLs identified for biofortification traits in Rice.

\begin{tabular}{|c|c|c|c|c|c|c|}
\hline Cross & $\begin{array}{l}\text { Population } \\
\text { type and } \\
\text { size }\end{array}$ & \begin{tabular}{|l|} 
No. of \\
total \\
QTLs
\end{tabular} & \begin{tabular}{l|} 
PVE \\
range \\
(additive \\
effect \\
QTLs) \\
\end{tabular} & $\begin{array}{l}\text { Chromosomes/ } \\
\text { chromosome } \\
\text { arms }\end{array}$ & Marker intervals / nearest markers for major QTL (PVE) & References \\
\hline \multicolumn{7}{|l|}{ Amino acid content } \\
\hline $\begin{array}{l}\text { Indica rice (Zhenshan 97) } \times \\
\text { Indica rice (Nanyangzhan) }\end{array}$ & RILs (190) & \begin{tabular}{ll|}
2 & $\mathrm{QTL}$ \\
clusters*
\end{tabular} & $\begin{array}{l}4.05- \\
33.3\end{array}$ & 1,7 & $\begin{array}{l}\text { RM472-RM104 } \\
\text { (Asp/Thr/Gly/Ala/Tyr/Pro/Lys/Ser/Glu/Asp/Val/Met/lle/Leu/Phe/His/Arg/Cys) } \\
\text { (5.7-33.3), }\end{array}$ & 39 \\
\hline $\begin{array}{l}\text { Indica rice }(\text { Zhenshan 97) } \times \\
\text { Indica rice (Minghui 63) }\end{array}$ & RILs (241) & $\begin{array}{l}10 \\
(\mathrm{His})+8 \\
(\mathrm{Arg})\end{array}$ & $\begin{array}{l}12-35 \\
\text { (His); } \\
16-33 \\
(\mathrm{Arg})\end{array}$ & $\begin{array}{l}1,2,3,6,7,10 \\
11,12 \text { (His); } 2 \\
3,5,6,7,10 \\
11,12\end{array}$ & $\begin{array}{l}\text { R321-RM55 (12), RZ398-RM204 (12), RG101-G393 (15), C1003B-RG103 } \\
\text { (15), RG118-C794 (20), RM53-RZ599 (22), RM258-RG561 (22), RG424- } \\
\text { R2549 (23), RG528-RG128 (24), RM20b-C732 (35) [His]; C734b-RZ649 } \\
\text { (16), R321-RM55 (18), RG424-R2549 (21),RM258-RG561 (21), R3203- } \\
\text { RM20A (22), RM53-RZ599 (23), RG528-RG128 (23), RM20b-C732 (33) }\end{array}$ & 40 \\
\hline $\begin{array}{l}\text { Indica rice (Zhenshan 97) } \times \\
\text { Indica rice (Minghui 63) }\end{array}$ & RILs (241) & 12 & $3.4-48.8$ & 1,11 & $\begin{array}{l}\text { R2632-C39 (Ser) (13.5), RG173-RM81A (Val) (14.5), RZ536-TEL3 (Met) } \\
\text { (48.8) }\end{array}$ & 61 \\
\hline $\begin{array}{l}\text { Indica rice (Zhenshan 97B) } \times \\
\text { Indica rice (Delong 208) }\end{array}$ & RILs (188) & \begin{tabular}{ll|}
3 & QTL \\
clusters*
\end{tabular} & $4.2-31.7$ & $1,7,9$ & $\begin{array}{l}\text { RM328-RM107 (Asp/Thr/Ser/Gly/Val//le/Phe/Lys/Taa) } \quad \text { (13.2), MRG186- } \\
\text { MRG4499(Asp/Thr/Ser/Glu/Gly/ Ala/Cys/Val/Met//le/Phe/Arg/Pro/Taa) }(14.4- \\
\text { 27.5), RM493-RM562 (Asp/Thr/Glu/Gly/Ala/Val/Leu/Phe/ Arg/Pro/Taa) }(24.2 \\
\text { 31.7), }\end{array}$ & 25 \\
\hline $\begin{array}{l}\text { O. sativa (Dasanbyeo) } \times \\
\text { O.sativa (TR22183) }\end{array}$ & RILs (172) & 6 & $\begin{array}{l}10.2- \\
12.4\end{array}$ & 3 & $\begin{array}{l}\text { id3015453-id3016090 (Ala-10.2, Phe-10.6, Iso-11.2, Val-12.4, Leu-12.4), } \\
\text { id3001422 fd10 (Lys-10.8) }\end{array}$ & 41 \\
\hline \multicolumn{7}{|l|}{ Protein content } \\
\hline $\begin{array}{l}\text { Indica rice (Zhenshan 97) } \times \\
\text { Indica rice (Minghui 63) }\end{array}$ & RILs (238) & 2 & $6.0-13.0$ & 6,7 & C952-Wx (13) & 23 \\
\hline $\begin{array}{l}\text { Indica rice (Caiapo) } \times \\
\text { Oryzaglaberrima } \quad \text { (IRGC } \\
\text { 103544) }\end{array}$ & $\begin{array}{l}\text { DH lines } \\
(312)\end{array}$ & 4 & 4.8-15.0 & $1,2,6,11$ & RM226-RM297 (15) & 24 \\
\hline $\begin{array}{l}\text { Indica rice }(\text { Gui630 }) \times \\
\text { Japonica rice }(02428)\end{array}$ & $\begin{array}{ll}\text { DH } & \text { lines } \\
(81) & \end{array}$ & 5 & $6.9-35.0$ & $1,4,5,6,7$ & C22-RG449d (16.5), ZG34B-G20 (22.5), RG435-RG172a (35.0) & 62 \\
\hline $\begin{array}{lr}\text { O. sativa } \\
\text { glaberrima }\end{array} \quad$ (V20A) $\times$ O & $\begin{array}{l}\text { BC3(TC)F1 } \\
\text { families } \\
(308)\end{array}$ & 1 & $9.0-10.0$ & L & & 63 \\
\hline Japonica rice (Moritawase) $\times$ & RILs (92) & 3 & $2.3-16.3$ & $2,6,9$ & & 64 \\
\hline
\end{tabular}




\begin{tabular}{|c|c|c|c|c|c|c|}
\hline Japonica rice (Koshihikari) & & & & & & \\
\hline $\begin{array}{lll}\text { Koshihikari/ } & \text { Indica } & \text { rice } \\
\text { (Kasalath)// } & \text { Japonica } & \text { rice } \\
\text { (Koshihikari) } & & \end{array}$ & BILs (92) & 2 & $\begin{array}{l}14.3- \\
14.8\end{array}$ & 6,10 & R1952 (14.3), R2447 (14.8) & 65 \\
\hline $\begin{array}{l}\text { Indica rice }(\text { Chuan) } \times \\
\text { Japonica rice (Nanyangzhan) }\end{array}$ & RILs (286) & 2 & $\begin{array}{l}2.69- \\
4.50\end{array}$ & 6,7 & & 66 \\
\hline $\begin{array}{l}\text { Indica rice (Xieqingzao B) } \times \\
\text { Indica rice (Milyang 46) }\end{array}$ & RILs (209) & 5 & $3.9-19.3$ & $3,4,5,6,10$ & RM251-RM282 (10.5), RM190-RZ516 (19.3) & 67 \\
\hline $\begin{array}{l}\text { Indica rice (Zhenshan 97) } \times \\
\text { Indica rice (Minghui 63) }\end{array}$ & RILs (241) & 9 & $\begin{array}{l}1.60- \\
9.26\end{array}$ & $\begin{array}{l}2,3,5,6,7,10 \\
11,12\end{array}$ & & 68 \\
\hline $\begin{array}{l}\text { Tongil variety (Samgang) } \times \\
\text { Japonica variety (Nagdong) }\end{array}$ & $\begin{array}{ll}\text { DH } & \text { lines } \\
(120) & \end{array}$ & 3 & $\begin{array}{l}6.92- \\
22.98\end{array}$ & 1,11 & RM287-RM26755 (21.21), 11025-RM287 (22.98) & 69 \\
\hline $\begin{array}{l}\text { Japonica rice (Asominori) } \times \\
\text { Indica rice (IR24) }\end{array}$ & CSSLs (66) & 9 & $3.0-53.7$ & $1,2,3,6,8,11$ & R1982 (10.4-14.2), XNpb113 (12.0-13.8), C1350 (23.6), G1149 (13.0-53.7) & 70 \\
\hline $\begin{array}{l}\text { Japonica rice (Asominori) } \times \\
\text { Indica rice }(\text { IR24) }\end{array}$ & RILs (71) & 10 & $\begin{array}{l}8.53- \\
23.70\end{array}$ & $\begin{array}{l}1,3,4,6,7,8 \\
9,10,12\end{array}$ & $\begin{array}{lllll}\text { R265B-XNpb36 } & \text { (10.50), C1003-C688 (12.67), XNpb212-G1318 } & \text { (13.86), } \\
\text { C606-XNpb238 } & \text { (14.63), R1854-R2373 (15.65), XNpb24-C562 } & \text { (17.60), } \\
\text { XNpb338-C796 (19.59), R758-XNpb15 (19.74), XNpb268-R411 (23.70), }\end{array}$ & 30 \\
\hline $\begin{array}{l}\text { Indica rice (Zhenshan 97B) } \times \\
\text { Indica rice (Delong 208) }\end{array}$ & RILs (188) & 2 & 7.2-25.9 & 1,7 & RM445-RM418 (25.9) & 25 \\
\hline $\begin{array}{lll}\text { Koshihikari/ } & \text { Indica } & \text { rice } \\
\text { (Kasalath)// } & \text { Japonica } & \text { rice } \\
\text { (Koshihikari) } & & \end{array}$ & BILs (182) & 4 & $\begin{array}{l}6.26- \\
12.11\end{array}$ & $2,3,7,10$ & R250-C746 (10.04), C16-C809 (11.07), C847-C596 (12.11) & 26 \\
\hline $\begin{array}{l}\text { Indica rice (Cheongcheong) } \\
\times \text { Indica rice (Nagdong) }\end{array}$ & $\begin{array}{ll}\text { DH } & \text { lines } \\
(133) & \end{array}$ & 1 & $39-41$ & 2 & RM12532-RM555 (39-41) & 27 \\
\hline $\begin{array}{l}\text { Japonica cultivar }(\mathrm{CJ} 06) \times \\
\text { Indica rice cultivar }(\mathrm{TN} 1)\end{array}$ & $\begin{array}{ll}\text { DH } & \text { lines } \\
(116) & \end{array}$ & $1^{*}$ & $\begin{array}{l}12.3- \\
15.8\end{array}$ & 10 & RM216-RM467 (12.3-15.8) & 28 \\
\hline $\begin{array}{l}\text { Indica rice (Cheongcheong) } \\
\times \text { Indica rice (Nagdong) }\end{array}$ & $\begin{array}{ll}\text { DH lines } \\
(133)\end{array}$ & 3 & $39-40$ & $8,9,10$ & RM506-RM1235 (39), RM24934-RM25128 (40), RM219-RM23914 (40) & 29 \\
\hline $\begin{array}{l}\text { O. sativa(M201) } \times \text { O. sativa } \\
(\text { JY293) }\end{array}$ & RILs (234) & $5 \$$ & $\begin{array}{l}6.74- \\
13.50\end{array}$ & $1,2,3,4$ & RM423-RM6375 (11.72), GS3-SLAF13430 (13.50) & 31 \\
\hline $\begin{array}{l}\text { Japonica } \quad \text { variety } \\
(\text { Sasanishiki }) \times \text { Indica variety } \\
(\text { Habataki) }\end{array}$ & CSSLs (39) & $1 \#$ & $\begin{array}{l}10.38- \\
15.43\end{array}$ & 1 & RM7124 (10.38-15.43) & 33 \\
\hline $\begin{array}{l}\text { Indica rice (Cheongcheong) } \\
\times \text { Indica rice (Nagdong) }\end{array}$ & $\begin{array}{ll}\text { DH } & \text { lines } \\
(120) & \end{array}$ & 1 & 14 & 7 & RM8261 (14) & 34 \\
\hline Naveen/ O. sativa (ARC & BC3F5 & $3^{*}$ & $6.70-$ & $1,2,7$ & CSCWR_Os01g02590_61041 (13.85), CSCWR_Os02g10740_65058 (6.70- & 35 \\
\hline
\end{tabular}




\begin{tabular}{|c|c|c|c|c|c|c|}
\hline 10075)//O. sativa (Naveen) & lines (200) & & 17.35 & & 17.35) & \\
\hline \multicolumn{7}{|l|}{ Iron and Zinc } \\
\hline $\begin{array}{l}\text { Indica variety (IR64) } \times \\
\text { Japonicavariety (Azucena) }\end{array}$ & $\begin{array}{ll}\text { DH } & \text { lines } \\
(129)\end{array}$ & $\begin{array}{l}\text { GZn-2; } \\
\text { GFe-3 }\end{array}$ & $\mathrm{q}$ & 1,$12 ; 2,8,12$ & $\begin{array}{l}\text { RM235-RM17 (12.8), RM34-RM237 (15) [GZn]; RM270-RM17 (13.8), } \\
\text { RM53-RM300 (16.5), RM137-RM325A (18.3) [GFe] }\end{array}$ & 18 \\
\hline $\begin{array}{l}\text { Indica cultivar (Zhengshan } \\
97) \times \text { Indica cultivar } \\
\text { (Minghui 63) }\end{array}$ & RILs (241) & $\begin{array}{l}\mathrm{GZn}-3 ; \\
\mathrm{GFe}-2\end{array}$ & $\begin{array}{l}5.3- \\
18.61 \\
11.11- \\
25.81\end{array}$ & $5,7,11 ; 1,9$ & $\begin{array}{l}\text { R3166-RG360 (12.34), C794-RG118 (18.61) [GZn]; C472-R2638 (11.11), } \\
\text { RG236-C112 (25.81) [GFe] }\end{array}$ & 45 \\
\hline $\begin{array}{l}\text { O. sativa ssp. Indica } \\
(\text { Teqing }) \times \text { O. rufipogonGriff. }\end{array}$ & ILs (85) & $\begin{array}{l}\mathrm{GZn}-2 * \\
\mathrm{GFe}-1 *\end{array}$ & $5-11 ; 7$ & 5,$8 ; 2$ & RM152 (11) [Zn] & 17 \\
\hline $\begin{array}{l}\text { Indica rice }(\text { Bala }) \times \text { Japonica } \\
\text { rice }(\text { Azucena) }\end{array}$ & RILs (79) & $\begin{array}{l}\text { GZn-4; } \\
\text { GFe- } 4\end{array}$ & $\begin{array}{l}11.2- \\
14.8 \\
9.7-21.4\end{array}$ & $\begin{array}{l}6,7,10 ; 1,3,4 \\
7\end{array}$ & $\begin{array}{l}\text { G1082 (11.2), G20 (11.4), AB0601 (14.7), C223 (14.8) [GZn]; R1440 (15.5), } \\
\text { C949 (16.2), R1618 (21.4) [GFe] }\end{array}$ & 46 \\
\hline $\begin{array}{l}\text { Indica cultivar (ZYQ8) } \mathrm{x} \\
\text { Japonica cultivar (JX17) }\end{array}$ & $\begin{array}{ll}\text { DH } & \text { lines } \\
(127) & \end{array}$ & GZn-2 & $\begin{array}{l}10.83- \\
12.38\end{array}$ & 4,6 & CT206-G177 (10.83), RZ516-G30 (12.38) [GZn] & 47 \\
\hline $\begin{array}{l}\text { Indica rice (Madhukar) } \times \\
\text { Indica rice }(\text { Swarna })\end{array}$ & RILs (168) & $\begin{array}{l}\text { GZn-6; } \\
\text { GFe-7 }\end{array}$ & $\begin{array}{l}29-35 \\
69-71\end{array}$ & $\begin{array}{l}3,7,12 ; 1,5,7 \\
12\end{array}$ & $\begin{array}{l}\text { RM501-OsZip2 (29), RM7-RM517 (31), RM260-RM7102 (34), RM234- } \\
\text { RM248 (35), RM248-RM8007 (35), RM17-RM260 (35) [GZn]; RM243- } \\
\text { RM488 (69), RM488-RM490 (69.2), RM574-RM122 (69.2), RM234-RM248 } \\
\text { (69), RM248-RM8007 (69), RM17-RM260 (71), RM 260-RM7102 (71) [GFe] }\end{array}$ & 48 \\
\hline $\begin{array}{l}\text { Indica rice (PAU201) } \quad x \\
\text { Indica rice (Palman 579) }\end{array}$ & F2 (247) & $\begin{array}{l}\text { GZn-3; } \\
\text { GFe- } 8\end{array}$ & $\begin{array}{l}4.7-19.1 \\
2.4-26.8\end{array}$ & $\begin{array}{l}2,10 ; 2,3,7 \\
10,12\end{array}$ & $\begin{array}{l}\text { 8RM474-RM184 (19.1) [Zn]; RM491-RM519 (16.9), RM228-RM496 (18.1), } \\
\text { RM53-RM521 (21.4), RM221-RM208 (26.8) }\end{array}$ & 49 \\
\hline $\begin{array}{l}\text { Indica cultivar (Ce258) } \mathrm{x} \\
\text { Japonicabreeding line } \\
\text { (IR75862) \& Indica cultivar } \\
\text { (ZGX1) x Japonicabreeding } \\
\text { line (IR75862) }\end{array}$ & $\begin{array}{l}\text { BILs }(200 \\
\text { and 201) }\end{array}$ & $\begin{array}{l}\mathrm{GZn}-4 * \\
\mathrm{GFe}-1 *\end{array}$ & $\begin{array}{l}2-24.4 \\
10.2- \\
18.3\end{array}$ & $3,6,7,8 ; 6,11$ & $\begin{array}{l}\text { RM293- RM85 (11.1-14.4), RM407- RM152 (11.2-18.0) [GZn]; RM3- } \\
\text { RM340 (10.2-18.3) [GFe] }\end{array}$ & 31 \\
\hline $\begin{array}{l}\text { Indica cultivar (Swarna) X } \\
\text { Japonica rice (Moroberekan) }\end{array}$ & RILs (60) & GFe-1 & 39 & 1 & RM490-RM5 (39) & 50 \\
\hline $\begin{array}{l}\text { O. sativa }(\mathrm{XB}) \times \quad \mathrm{O} . \\
\text { rufipogon }(\text { acession of } \mathrm{DWR})\end{array}$ & BILs (202) & $\begin{array}{l}\text { GZn-6; } \\
\text { GFe-3 }\end{array}$ & $\begin{array}{l}5.3-11.8 \\
6.1-28.2\end{array}$ & $\begin{array}{l}3,4,6,7,10 \\
12 ; 3,6,9\end{array}$ & RG172-RM340 (11.8) [GZn]; RG123-RG172 (16.7), RG510-RZ251 (28.2) & 51 \\
\hline $\begin{array}{l}\text { O.sativa } \\
\text { (Nipponbare)/O.meridionalis } \\
\text { (W1627)//Nipponbare }\end{array}$ & $\begin{array}{l}\text { BRILs } \\
(151)\end{array}$ & GZn-4 & $\begin{array}{l}15.0- \\
21.9\end{array}$ & $2,9,10$ & RM171-RM590 (15.0), RM573 (15.2), RM6 (17.6), RM24085-RM566 (21.9) & 52 \\
\hline $\begin{array}{l}\text { Indica cultivar (PSBRc82) } \mathrm{x} \\
\text { Korean rice (Joryeongbyeo) } \\
\& \quad \text { PSBRc82 } \quad \mathrm{x} \text { Indica }\end{array}$ & $\begin{array}{l}\text { DH lines } \\
(130 \& 97)\end{array}$ & $\begin{array}{l}\text { GZn-8; } \\
\text { GFe-1 }\end{array}$ & $\begin{array}{l}7.5-22.8 \\
9.4\end{array}$ & $\begin{array}{l}2,3,6,8,11 \\
12 ; 4\end{array}$ & $\begin{array}{l}2140834-2147095(10.3), 13048465-13057679(12.3), 8803052-8832534(14.3), \\
6025827-6047367 \quad(15.3), 606341-\operatorname{id} 6006214 \quad(16.1), 2110566-i d 2009463 \\
(17.3), 2783884-2785595(20.3), 10858811-i d 11000778(22.8)[\mathrm{GZn}]\end{array}$ & 53 \\
\hline
\end{tabular}




\begin{tabular}{|c|c|c|c|c|c|c|}
\hline breeding line (IR69428) & & & & & & \\
\hline $\begin{array}{l}\text { Indica cultivar (IR64) } \\
\text { Breeding line (IR69428) } \& \\
\text { Indica cultivar (BR29) } \\
\text { Breeding line (IR75862) }\end{array}$ & $\begin{array}{lr}\text { DH } & \text { lines } \\
(111 & \& \\
146) & \end{array}$ & GZn-8 & $8.6-27.7$ & $\begin{array}{l}2,3,5,7,8,9, \\
11\end{array}$ & 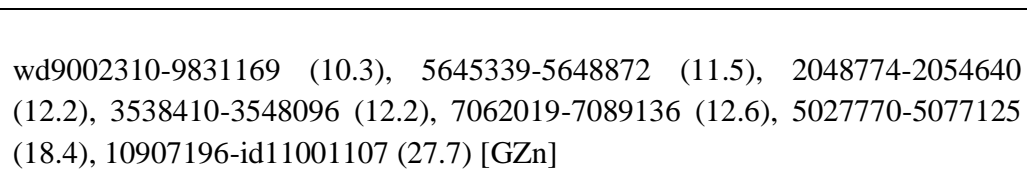 & 54 \\
\hline $\begin{array}{l}\text { Indica rice (PAU201) } \mathrm{x} \\
\text { Indica rice (Palman) }\end{array}$ & $\begin{array}{l}\text { F4 } \\
\text { Population } \\
(579)\end{array}$ & $\begin{array}{l}\text { GZn-1; } \\
\text { GFe-5 }\end{array}$ & $\begin{array}{l}25 ; 34.6- \\
95.2\end{array}$ & $6 ; 5,7,9$ & $\begin{array}{l}\text { RM585-RM3 (25) [GZn]; RM2488-RM440 (64.1), RM440-RM31 (95.2), } \\
\text { RM440-RM31 (95.2), RM432-RM429 (95.2), RM566-RM434 (36.6) [GFe] }\end{array}$ & 55 \\
\hline
\end{tabular}

